\title{
CROPS AND SOILS RESEARCH PAPER Ammonia loss from urea in grassland and its mitigation by the new urease inhibitor 2-NPT
}

\author{
M. SCHRAML ${ }^{1}$, R. GUTSER ${ }^{1}$, H. MAIER ${ }^{2}$ AND U. SCHMIDHALTER ${ }^{1}$ \\ ${ }^{1}$ Chair of Plant Nutrition, Department of Plant Sciences, Technische Universität München, Emil-Ramann-Straße 2, 85350 \\ Freising, Germany \\ ${ }^{2}$ Deutscher Wetterdienst, Agrarmeteorologie Weihenstephan, Alte Akademie 16, 85354 Freising, Germany
}

(Received 27 July 2014; revised 23 September 2015; accepted 5 January 2016; first published online 4 March 2016)

\section{SUMMARY}

Following the surface application of granulated urea to grassland, high ammonia $\left(\mathrm{NH}_{3}\right)$ losses of up to $30 \%$ have been reported. The addition of a urease inhibitor (UI) to urea granules could be a way to abate these losses. Field experiments were conducted at two intensive grassland sites in 2007 and 2008 to evaluate the potential of the new UI N-(2-nitrophenyl) phosphoric triamide (2-NPT; concentrations of $0.75,1.0$ and $1.5 \mathrm{~g} \mathrm{~N} / \mathrm{kg}$ ) to reduce $\mathrm{NH}_{3}$ emissions resulting from the application of granulated urea. Ammonia losses were continuously measured on plots fertilized with urea, urea $+2-\mathrm{NPT}$, calcium ammonium nitrate and a control $(0 \mathrm{~N})$. The measurements were made with a dynamic chamber system. All measurement periods were started after a period of precipitation with a following rainless period being forecasted. Results over measurement periods of 10 days following fertilization are presented. Ammonia losses following the application of granulated urea varied between 4.6 and 11.8 $\mathrm{kg} \mathrm{N} / \mathrm{ha}$, corresponding to $4 \cdot 2$ up to $14 \cdot 0 \%$ of the applied nitrogen. The addition of 2-NPT to urea granules at three concentrations significantly reduced $\mathrm{NH}_{3}$ losses by $69-100 \%$. Comparable losses of $\mathrm{NH}_{3}$ were observed for urea containing the UI 2-NPT as well as calcium ammonium nitrate, and were not significantly different from the control treatment. No relationships between losses, meteorological factors and soil moisture were observed. The addition of the UI 2-NPT to urea granules applied on grassland effectively reduced $\mathrm{NH}_{3}$ losses.

\section{INTRODUCTION}

Urea $\left(\mathrm{CO}\left(\mathrm{NH}_{2}\right)_{2}\right)$ is the most important fertilizer worldwide, with a world market share of $57 \%$ in mineral nitrogen $(\mathrm{N})$ fertilizer consumption (IFADATA 2015). In the presence of water, urea is quickly hydrolysed to ammonia $\left(\mathrm{NH}_{3}\right)$, hydroxyl $\left(\mathrm{OH}^{-}\right)$ions and carbon dioxide by the ubiquitous enzyme urease (Zaman \& Blennerhassett 2010). This hydrolysis reaction results in an elevated $\mathrm{pH}$ surrounding the fertilizer granule, which switches the ammonium $\left(\mathrm{NH}_{4}^{+}\right) / \mathrm{NH}_{3}$-equilibrium towards a higher $\mathrm{NH}_{3}$ concentration in the soil solution and induces high emissions of $\mathrm{NH}_{3}$ into the atmosphere (Sommer et al. 2004). Part of the emitted $\mathrm{NH}_{3}$ is deposited on vegetation surfaces, where it causes acidification and eutrophication on a regional scale. Its impact is great, especially when deposited in natural and

\footnotetext{
* To whom all correspondence should be addressed. Email: martineschraml@googlemail.com
}

semi-natural ecosystems, and can result in an ecological shift in species diversity (Van Breemen et al. 1982; Bouwman \& Van Vuuren 1999).

Among other things, the length and extent of the phase during which these losses occur depends on climatic parameters, such as temperature and precipitation (Ernst \& Massey 1960; Black et al. 1987; Sherlock et al. 1995; Sommer et al. 2004). On grassland, $\mathrm{NH}_{3}$ losses following urea application vary between 6 and $30 \%$ of applied $\mathrm{N}$ and occur within a period of 3-7 days, with the maximum rate being recorded on days 1-3 following fertilization (Black et al. 1987; Watson et al. 1994; Sherlock et al. 1995; Van Der Weerden \& Jarvis 1997; Dawar et al. 2011; Sanz-Cobena et al. 2011).

These losses of $\mathrm{NH}_{3}$ from urea can be inhibited by immediately incorporating the fertilizer into the soil (Sommer et al. 2004). However, when $\mathrm{N}$ is applied to grassland, mechanical incorporation into the soil usually disturbs the grass sward and is therefore not 
Table 1. Soil characteristics of the experimental sites

\begin{tabular}{|c|c|c|c|c|c|c|c|c|c|}
\hline Site & Year & Soil type & $\begin{array}{l}\mathrm{pH} \\
\left(\mathrm{CaCl}_{2}\right)\end{array}$ & Clay (\%) & Silt (\%) & Sand $(\%)$ & $\begin{array}{l}\text { Urease activity ( } \mu \mathrm{g} \\
\mathrm{N}(\mathrm{g} \text { DM/soil)/2 h) }\end{array}$ & $\begin{array}{l}C_{\text {org }} \\
(\% \text { DM })\end{array}$ & $\begin{array}{l}\text { CEC (cmol } \\
(\mathrm{kg} / \mathrm{soil}))\end{array}$ \\
\hline Veitshof & 2007 & $\begin{array}{l}\text { Endofluvic } \\
\text { Chernozem }\end{array}$ & $7 \cdot 2$ & $26 \cdot 8$ & $45 \cdot 7$ & $27 \cdot 5$ & 557 & $7 \cdot 1$ & $26 \cdot 9$ \\
\hline Dürnast & 2008 & Cambisol & $5 \cdot 7$ & $28 \cdot 1$ & $46 \cdot 6$ & $25 \cdot 3$ & 210 & $10 \cdot 65$ & $14 \cdot 18$ \\
\hline
\end{tabular}

$\mathrm{C}_{\text {org, }}$ organic carbon; $\mathrm{CEC}$, cation exchange capacity.

economically viable. One possibility for avoiding $\mathrm{NH}_{3}$ emissions following the application of urea to grassland is the use of a urease inhibitor (UI) (Saggar et al. 2013). These inhibitors reversibly block the active centre of the enzyme urease, thus impeding the hydrolysis of urea (Medina \& Radel 1988). Ideally, this effect should last until the next precipitation, which dilutes urea at the soil surface and moves it into the soil, where it is safe from being lost as $\mathrm{NH}_{3}$ (Watson 2000).

Many Uls have been tested, which show greater or lesser effects on mitigation of $\mathrm{NH}_{3}$ emissions (Medina \& Radel 1988; Watson 2000). The most widely used $\mathrm{UI}$ is nBTPT or 'Agrotain', which is capable of reducing $\mathrm{NH}_{3}$ emissions following the application of granulated urea to grassland by 45-65\% (Dawar et al. 2011). However, nBTPT is not the active form and has to be converted into its oxygen analogue first, which can delay its efficiency by minutes, hours or even days (Saggar et al. 2013). From 2001 to 2006, in two approved joint projects financed by the German Federal Ministry of Education and Research, Stickstoffwerke Piesteritz $\mathrm{GmbH}$ together with Humboldt Universität zu Berlin, Martin-Luther-Universität Halle-Wittenberg and Technische Universität München (Support code 0330202) developed and tested new Uls on their efficiency to reduce $\mathrm{NH}_{3}$ emissions following the application of granulated and liquid urea. $\mathrm{N}$-(2-nitrophenyl) phosphoric triamide (2-NPT) turned out to be the most promising UI (Hucke et al. 2010). It is very stable during storage and has been shown to reduce $\mathrm{NH}_{3}$ emission from granulated urea applied to winter wheat by 26-83\% (Ni et al. 2014).

The present work now aims to evaluate the potential of this new UI 2-NPT to reduce $\mathrm{NH}_{3}$ emissions following the application of granulated urea to grassland.

\section{MATERIALS AND METHODS}

\section{Experimental sites}

In both years 2007 and 2008, field experiments were carried out from late May to late July. They were conducted on two permanent grassland sites in Southern Germany. In 2007, the experimental site was at Veitshof $\left(48^{\circ} 24^{\prime} \mathrm{N}, 11^{\circ} 41^{\prime} \mathrm{E}, 446 \mathrm{~m}\right.$ a.s.l.). To evaluate the efficiency of the UI 2-NPT on a second site, in 2008, experiments were conducted at Dürnast $\left(48^{\circ} 40^{\prime} \mathrm{N}, 11^{\circ} 69^{\prime} \mathrm{E}, 485 \mathrm{~m}\right.$ a.s.l.). Both sites consisted of an established sward of perennial ryegrass (Lolium perenne L.), which was cut four or five times per year, mainly for silage production.

Soils were Endofluvic Chernozem in 2007 and Cambisol in 2008, according to IUSS Working Group WRB (2007).

Soil analysis

Prior to the experiment, representative soil samples were taken from a depth of $0-0 \cdot 15 \mathrm{~m}$ and analysed for the parameters listed in Table 1. Soil pH was determined following Schofield \& Taylor (1955; $0.01 \mathrm{M}$ $\mathrm{CaCl}_{2}$ ). Soil texture was analysed in compliance with Gee \& Bauder (1986), whereby organic matter first had to be removed by the use of hydrogen peroxide $\left(\mathrm{H}_{2} \mathrm{O}_{2}\right)$. Urease activity was determined using a $0.01 \mathrm{M} \mathrm{CaCl}_{2}$ solution following the unbuffered method of Kandeler \& Gerber (1988) and cation exchange capacity following extraction into a buffered $0 \cdot 1 \mathrm{M} \mathrm{BaCl}_{2}$ solution $(\mathrm{pH} 8 \cdot 1)$. Organic carbon content $\left(\mathrm{C}_{\text {org }}\right)$ was calculated as $\left(\mathrm{C}_{\text {org }}=\mathrm{C}_{\mathrm{t}}-\mathrm{C}_{\text {carb }}\right)$, with the total $\mathrm{C}$ content $\left(\mathrm{C}_{\mathrm{t}}\right)$ determined in a $\mathrm{C} / \mathrm{N}$-analyser (ANCA-NT system, Europa Scientific Ltd.) and the carbonatic carbon content $\left(\mathrm{C}_{\text {carb }}\right)$ measured following the volumetric calcimeter method (Loeppert \& Suarez 1996).

\section{Experimental setup}

In both years, the plots were $2 \times 5 \mathrm{~m}^{2}$ in size. Per measurement period, 12 plots were installed in a random block design for simultaneous comparison of four fertilizer treatments with three replicates. 
Four measurement periods were carried out in 2007 and three in 2008.

A measurement period lasted at least 10 days and was stopped when suitable climatic conditions for the start of the next period were expected. Thus, experimental periods lasted between 10 and 21 days. However, for a better comparison of the course and extent of $\mathrm{NH}_{3}$ losses in the current work, all measurement periods are reported over 10 days.

All experimental periods were started after a period of precipitation and as soon as a warmer and rainless phase was forecast, which ensured moist conditions at the soil surface and thus a better dissolution of the granules. Warm temperatures enhanced conditions for high $\mathrm{NH}_{3}$ losses. The only exception was the first measurement period in 2007, where soil conditions at the time of fertilization were dry.

The day before fertilization, the grassland of the plots to be measured was cut down to a stubble height of $0.05 \mathrm{~m}$ with a plot grass harvester. The granulated fertilizer was surface-applied using an exact plot fertilizer spreader. Straight after fertilization, the $\mathrm{NH}_{3}$ emission measurement system was installed and started.

In all measurement periods there was a control treatment which received no $\mathrm{N}(\mathrm{ON})$, and a treatment consisting of granulated urea. In 2007, the two additional fertilizer treatments were granulated urea +2-NPT in a concentration of $1.0 \mathrm{~g} / \mathrm{kg} \mathrm{N}$ and calcium ammonium nitrate (CAN). The CAN was chosen because it is the most widely used chemical fertilizer in Germany, where it accounts for $37 \%$ of $\mathrm{N}$ fertilizer consumption followed by urea with 21\% (IFADATA 2015). Therefore, it is often used as a reference point when comparing fertilizer efficiency. As no $\mathrm{NH}_{3}$ losses following the application of CAN were detected in 2007, CAN was left out in 2008. In that year, the two additional fertilizer treatments consisted of urea + 2NPT in two different concentrations of 0.75 and 1.5 $\mathrm{g} / \mathrm{kg} \mathrm{N}$. For all experimental periods, mineral fertilizer rate was $80 \mathrm{~kg} \mathrm{~N} / \mathrm{ha}$, which is a common dose per cut for intensively used grassland in Germany (Wendland et al. 2012).

CAN was obtained from the local distributor. Urea was provided by SKW Stickstoffwerke Piesteritz $\mathrm{GmbH}$ (Lutherstadt-Wittenberg, Germany). Application of the UI 2-NPT to the urea granule was carried out by SKW Stickstoffwerke Piesteritz $\mathrm{GmbH}$ and did not influence the granules' size of approximately $3 \mathrm{~mm}$ in diameter.

Harvesting of the experimental plots was performed using a plot grass harvester to determine biomass yields. Harvest dates were scheduled according to agronomic criteria, and in some cases had to be delayed due to climatic conditions. Therefore, harvesting took place 33-52 days after fertilization.

\section{Instrumentation and measurement}

A dynamic chamber system was used for $\mathrm{NH}_{3}$ measurements (Khalil et al. 2009). The 'open top'-chambers (Figs $1(\mathrm{a})$ and $(b)$; area $0.125 \mathrm{~m}^{2}$, height $0.40 \mathrm{~m}$, volume $0.05 \mathrm{~m}^{3}$ ) had a stainless steel ring on the bottom that was sunk into the soil by about $0.03 \mathrm{~m}$. The chamber's body consisted of acrylic glass. Heating wires were wound around the chamber to prevent surface condensation, which would cause adsorption of emitted $\mathrm{NH}_{3}$. The chamber was covered to permit inside air to flow out while simultaneously inhibiting the entry of external air. There were two measuring stations in operation, each equipped with six chambers (Fig. 1(C)). Each of the 12 chambers was installed on one of the 12 plots. Over the measurement periods of 10 days, the chambers were relocated daily within the plot, both to avoid a 'greenhouse' effect, and to record actual climatic influences on the occurrence of $\mathrm{NH}_{3}$ emissions.

Ventilators were used to collect ambient air $2 \mathrm{~m}$ above ground level and blow it tangentially into the chambers through $12 \mathrm{~m}$ of Teflon tubes (FluorethylenPropylen (FEP); inner diameter: $18 \mathrm{~mm}$ ) at an average volumetric flow rate of 40 litres/min (inlet velocity: $3 \cdot 3$ $\mathrm{m} / \mathrm{s}$ ). The air took up the emitted gaseous $\mathrm{N}$ and spiralled upwards to the tapered top of the chamber, where the sample collection system was installed. This system continuously drew a sample out of the air stream (wind velocity: $0.005 \mathrm{~m} / \mathrm{s}$ ) at a constant flow rate of 4 litres $/ \mathrm{min}$ from the chamber through $9 \mathrm{~m}$ of insulated (Foamed Polyurethane (PUR)) and heated $\left(50^{\circ} \mathrm{C}\right)$ Teflon tubing (FEP; inner diameter: $8 \mathrm{~mm}$ ). Before entering the measurement device, an upstream distribution system consisting of magnetic valves ensured that the air samples of the six chambers per measurement system were processed one at a time. The sampling time for a chamber varied between 15 and 30 min depending on the expected $\mathrm{NH}_{3}$ concentration in the sampled air and on the expected difference in the $\mathrm{NH}_{3}$ concentration from the sample in the preceding chamber.

The measurement device for the detection of the nitric oxide (NO) content in the air (CLD $700 \mathrm{AL}$, EcoPhysics, Gürnten, Switzerland) was based on the chemiluminescent gas phase reaction of $\mathrm{NO}$ with ozone $\left(\mathrm{O}_{3}\right)$. For this purpose, all $\mathrm{NO}_{x}$ and $\mathrm{NH}_{3}$ had to be converted into NO first. For nitrogen dioxide 


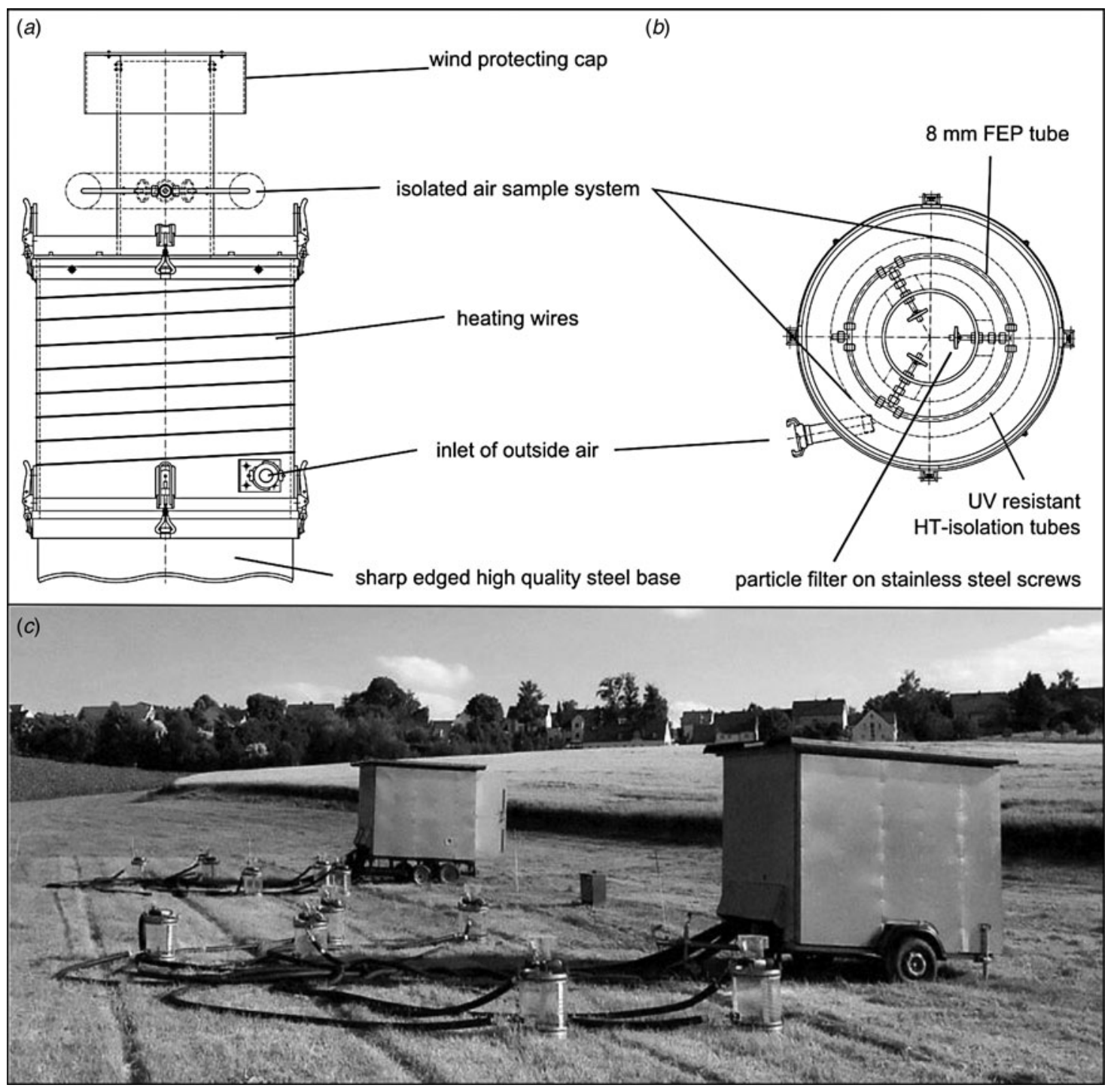

Fig. 1. Scheme of the dynamic chamber (a) and its sampling unit in the tapered top $(b)$. $\mathrm{NH}_{3}$ measurement system installed on the grassland experimental site Dürnast in 2008 (c).

$\left(\mathrm{NO}_{2}\right)$, this conversion was performed by a molybdenum (Mo) thermal converter $\left(3 \mathrm{NO}_{2}+\mathrm{Mo} \rightarrow 3\right.$ $\mathrm{NO}+\mathrm{MoO}_{3}$ ) at $375^{\circ} \mathrm{C}$. At a temperature of $600{ }^{\circ} \mathrm{C}$, $\mathrm{NH}_{3}$ was converted into $\mathrm{NO}$ by the addition of $\mathrm{O}_{3}$ in a stainless steel converter. The two-chamber principle of the measuring device divided the sampled air into two streams. One stream passed only through the Mo converter $\left([\mathrm{NOx}]=[\mathrm{NO}]+\left[\mathrm{NO}_{2}\right]\right)$, and the other passed through both, first the steel converter and then the Mo-converter ([NOx amines $]=$ $\left.[\mathrm{NOx}]+\left[\mathrm{NH}_{3}\right]\right)$. The concentration of $\mathrm{NO}$ within these two streams was measured in the photomultiplier (PMT). Thereafter, the $\mathrm{NH}_{3}$ content was calculated by $\left[\mathrm{NH}_{3}\right]=\left[\mathrm{NO} x_{\text {amines }}\right]-[\mathrm{NO} x]$. Samples were collected and analysed throughout the day, establishing the progression of $\mathrm{NH}_{3}$ emissions for every applied fertilizer treatment.

For every measurement day, the daily amount of $\mathrm{NH}_{3}$ emissions ( $\mathrm{g} \mathrm{NH}_{3}-\mathrm{N} / \mathrm{ha}$ and d) was calculated for each chamber by:

$$
F\left(\mathrm{NH}_{3}\right)=\rho_{\mathrm{N}} \Delta C Q A^{-1}
$$

where $F\left(\mathrm{NH}_{3}\right)$ is the $\mathrm{NH}_{3}$-flux (ng $\mathrm{N} /\left(\mathrm{m}^{2} s\right)$ ), $\rho_{\mathrm{N}}$ the standard density of the nitrogen in $\mathrm{NH}_{3}(\mathrm{ng} \mathrm{N} / \mathrm{nl}), \Delta c$ the concentration difference between sample and ambient air $(\mathrm{ppbv}=\mathrm{nl} / \mathrm{l}), Q$ the volume flow rate $(\mathrm{Nl} / \mathrm{s})$ and $A$ the chamber area $\left(0 \cdot 125 \mathrm{~m}^{2}\right)$. Daily emissions from each chamber were used for statistical evaluation. To determine the amount of $\mathrm{N}$ lost as $\mathrm{NH}_{3}$ following fertilizer application, average $\mathrm{NH}_{3}$ emissions detected on 
Table 2. Ammonia emissions ( $\mathrm{g} \mathrm{NH} \mathrm{N}_{3} \mathrm{~N} / \mathrm{ha}$ ) occurring within 10 days following the application of different fertilizer treatments in 2007 and 2008. Sums in $\mathrm{NH}_{3}$ emission, standard errors and LSD values are indicated

\begin{tabular}{|c|c|c|c|c|}
\hline & \multicolumn{4}{|c|}{ Day of fertilization } \\
\hline & 5 June 2007 & 19 June 2007 & 13 July 2007 & 26 July 2007 \\
\hline Urea & $4 \cdot 7 \pm 0 \cdot 60$ & $8 \pm 2 \cdot 6$ & $10 \pm 2 \cdot 0$ & $11 \cdot 8 \pm 0 \cdot 66$ \\
\hline Urea + 2-NPT 0.10\% & $1 \cdot 7 \pm 0.64$ & $3 \pm 1 \cdot 5$ & $4 \cdot 1 \pm 0 \cdot 49$ & $2 \cdot 3 \pm 0 \cdot 84$ \\
\hline Calcium ammonium nitrate & $1 \cdot 0 \pm 0 \cdot 23$ & $1 \cdot 7 \pm 0 \cdot 21$ & $1 \cdot 9 \pm 0.75$ & $1 \cdot 6 \pm 0 \cdot 21$ \\
\hline Control $(\mathrm{ON})$ & $1 \cdot 3 \pm 0 \cdot 25$ & $1 \cdot 6 \pm 0 \cdot 65$ & $1 \cdot 5 \pm 0 \cdot 42$ & $0 \cdot 7 \pm 0 \cdot 17$ \\
\hline \multirow[t]{3}{*}{ LSD value } & $1 \cdot 53$ & $5 \cdot 03$ & $3 \cdot 66$ & $1 \cdot 80$ \\
\hline & \multicolumn{3}{|c|}{ Day of fertilization } & \\
\hline & 26 May 2008 & 27 June 2008 & 10 July 2008 & \\
\hline Urea & $5 \pm 1 \cdot 8$ & $10 \cdot 2 \pm 0 \cdot 96$ & $4 \cdot 6 \pm 0 \cdot 64$ & \\
\hline Urea + 2-NPT 0.15\% & $0 \cdot 7 \pm 0.46$ & $3 \cdot 6 \pm 0 \cdot 69$ & $0 \cdot 5 \pm 0 \cdot 22$ & \\
\hline Urea + 2-NPT 0.075\% & $1 \cdot 4 \pm 0 \cdot 46$ & $3 \cdot 3 \pm 0 \cdot 15$ & $1 \cdot 1 \pm 0 \cdot 77$ & \\
\hline Control $(\mathrm{ON})$ & $0 \cdot 7 \pm 0.43$ & $0 \cdot 8 \pm 0 \cdot 24$ & $0 \cdot 5 \pm 0 \cdot 35$ & \\
\hline LSD value & $3 \cdot 24$ & 1.98 & $1 \cdot 76$ & \\
\hline
\end{tabular}

control plots were subtracted from average $\mathrm{NH}_{3}$ emissions measured on the fertilized plots.

\section{Climatic data}

For both sites, the long-time mean air temperature in the months of May, June and July is $12 \cdot 4,15 \cdot 1$ and $17 \cdot 0{ }^{\circ} \mathrm{C}$, respectively. Average precipitation in these months amounts to $77.5,97.5$ and $108.8 \mathrm{~mm}$, respectively.

In 2007, the Deutscher Wetterdienst (DWD) provided data on precipitation from a nearby weather station (located $3 \mathrm{~km}$ northwest of the experimental site) at a daily resolution. Soil temperature was measured at a depth of $0.05 \mathrm{~m}$ at the experimental site (Th2-h, UMS GmbH, Munich, Germany), except during the first measurement period, where the measurement system failed, and air temperature had also to be obtained from the DWD at a daily resolution.

In 2008, both, air temperature and precipitation were recorded by the DWD at the same weather station (now located $400 \mathrm{~m}$ east of the experimental site) used in 2007 and were provided at a resolution of $30 \mathrm{~min}$.

\section{Statistical evaluation}

All statistical evaluation was performed in $\mathrm{R}$ ( $\mathrm{R}$ Development Core Team 2011).

For each measurement period, fertilizer treatments (independent variable) were compared according to their $\mathrm{NH}_{3}$ emissions (dependent variable). For this, daily $\mathrm{NH}_{3}$ emissions (see earlier for calculation) occurring over the measurement period of 10 days were added up for every fertilizer treatment. As data were normally distributed, sums of $\mathrm{NH}_{3}$ emissions of all four fertilizer treatments were submitted to a POLYANOVA analysis to evaluate possible differences. Subsequently, data were subjected to a mean value analysis using Fisher's least significant difference (LSD) procedure $(P \leqslant 0.05)$. Grass yields were also subjected to an ANOVA.

Regression analyses were performed to investigate possible effects of climatic and soil factors on $\mathrm{NH}_{3}$ emissions. A multiple regression analysis could not be conducted, since only a few degrees of freedom were left.

\section{RESULTS}

Ammonia losses from the Veitshof site in 2007

The temperature course and distribution of rainfall events in the months of May-July were typical for an average year. Ammonia losses over 10 days of measurement following the application of granulated urea varied between 4.7 and $11.8 \mathrm{~kg} \mathrm{NH} \mathrm{H}_{3}-\mathrm{N} /$ ha (Table 2), corresponding to $4 \cdot 2$ up to $14.0 \%$ of the applied $\mathrm{N}$. In all experiments, the emissions started immediately following fertilization and peaked on the second day (Figs $2(a)-(d)$ ).

In the first experimental period, fertilizer was applied to dry soil, which resulted in comparatively 

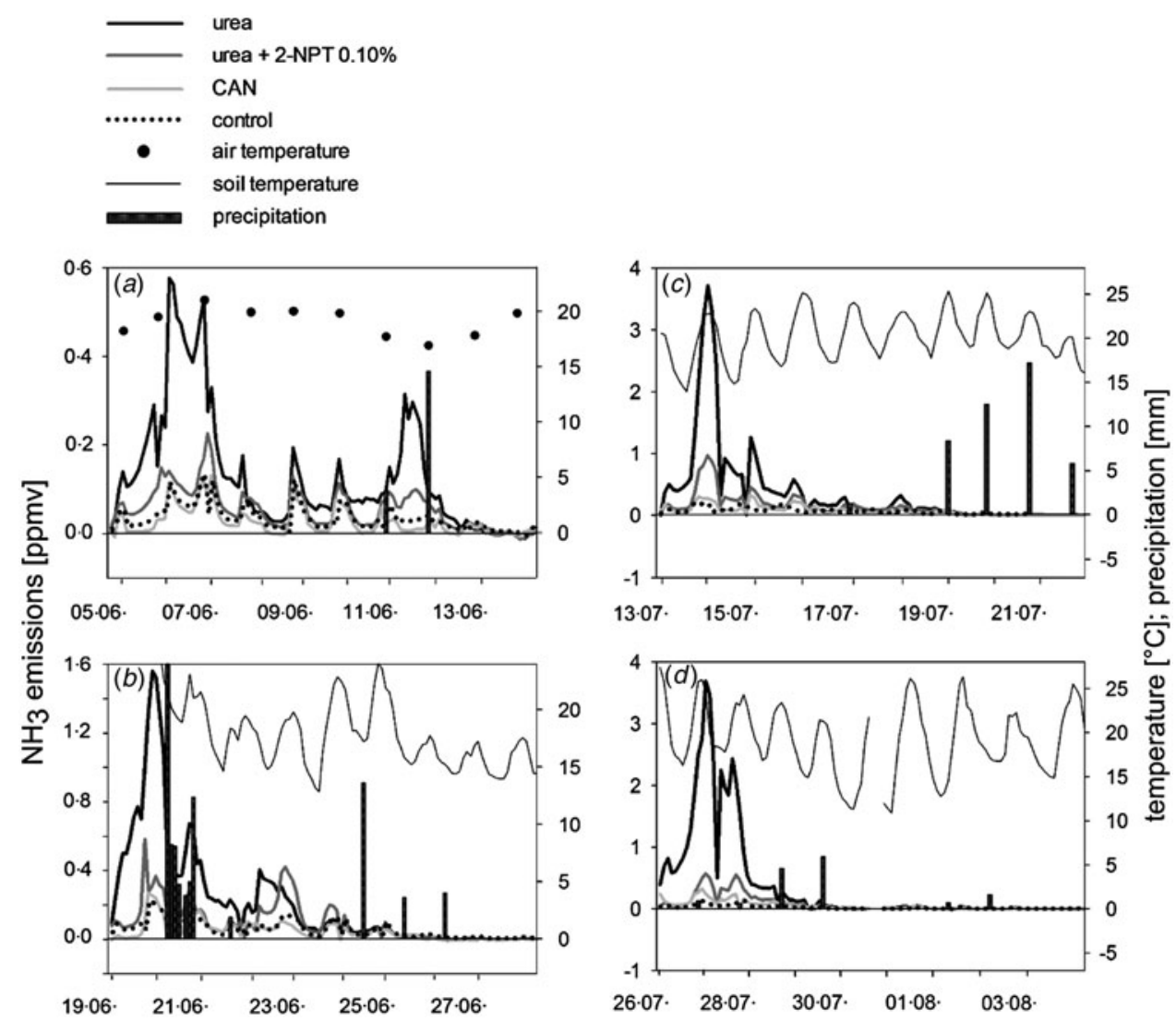

Fig. 2. Courses of $\mathrm{NH}_{3}$ emissions (ppmv) within 10 days following fertilization of urea, urea $+2-\mathrm{NPT}$ at a concentration of $1 \cdot 0$ $\mathrm{g} / \mathrm{kg} \mathrm{N}, \mathrm{CAN}$ and control $(\mathrm{ON})$ at the Veitshof experimental site in 2007 during four measurement periods (a-d). Precipitation $(a-d)$, air temperature $(a)$ and course of soil temperature $(b-d)$ are also indicated.

low losses of $4 \cdot 2 \%$ of the applied $N$ (Table 2), even though the temperatures during the loss phase were similar to the other experiments, with an average of $19 \cdot 7^{\circ} \mathrm{C}$, and even though the loss phase lasted for about 6 days longer than during the other 10-day measurement periods (Fig. 2(a)).

In the following experimental periods, fertilizer was applied following periods of precipitation. High moisture contents at the time of fertilization enabled a rapid dissolution of urea granules. In the absence of subsequent precipitation, more than $80 \%$ of the $\mathrm{NH}_{3}$ losses occurred within 3 days (Fig. 2(c)). Precipitation considerably reduced (Fig. 2(b)) or even terminated (Fig. 2(d)) the $\mathrm{NH}_{3}$ emissions.

In 2007, highly significant differences $(P \leqslant 0 \cdot 001)$ and significant differences $(P \leqslant 0.05)$ were detected between fertilizer treatments and application dates, respectively. However, no significant interaction was observed between treatments and application dates. In all experiments, the addition of the UI 2-NPT at a concentration of $1.0 \mathrm{~g} / \mathrm{kg} \mathrm{N}$ resulted in lower courses of $\mathrm{NH}_{3}$ volatilization. The $\mathrm{UI}$ reduced $\mathrm{NH}_{3}$ emissions by
69-88\%. Except for the second measurement, this reduction was significant $(P \leqslant 0.01$ for the first and third and $P \leqslant 0.001$ for the fourth measurement, respectively). Unlike urea, CAN was not significantly different from the control or 2-NPT treatment. $\mathrm{NH}_{3}-\mathrm{N}$ losses varied between 0 and $1 \cdot 2 \%$ of the fertilized $\mathrm{N}$ (Table 2).

No significant differences in yield were detected between fertilizer treatments, including the control. Therefore, yield data are not displayed and results are not discussed further.

Ammonia losses from the Dürnast site in 2008

In 2008, the first two 10-day measurement periods were performed during phases of above-average soil temperatures (by 5 and $3{ }^{\circ} \mathrm{C}$, respectively). As in 2007, fertilization was performed following a period of precipitation. The last experimental period was characterized by high rainfall of $22.0 \mathrm{~mm}$ on the second day of measurement.

Ammonia losses following the application of granulated urea varied between $4 \cdot 6$ and $10 \cdot 2 \mathrm{~kg} \mathrm{NH} \mathrm{NH}_{3} \mathrm{~N} / \mathrm{ha}$ 


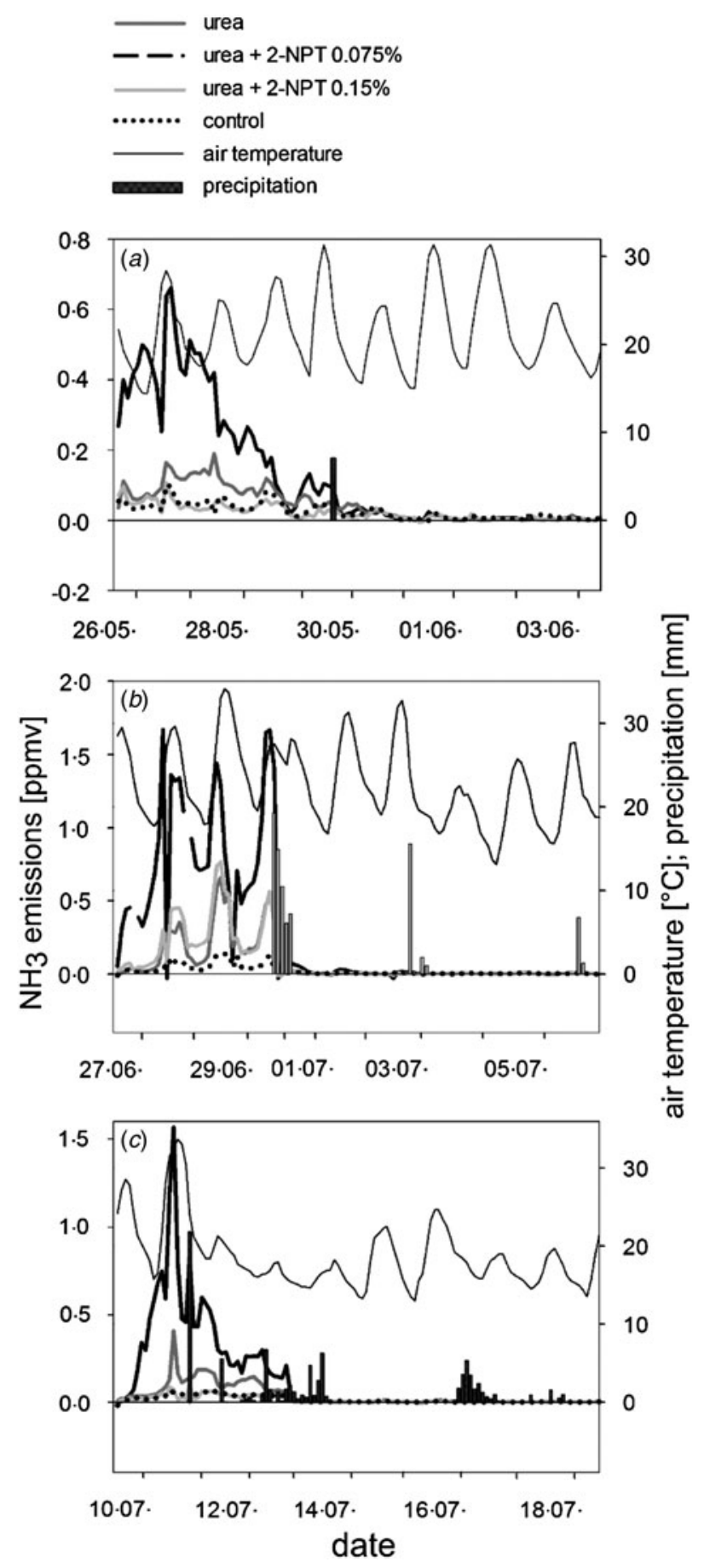

Fig. 3. Courses of $\mathrm{NH}_{3}$ emissions (ppmv) within 10 days following fertilization of urea, urea +2-NPT in concentrations of 0.75 and $1.5 \mathrm{~g} / \mathrm{kg} \mathrm{N}$ and control $(0 \mathrm{~N})$ at the Dürnast experimental site in 2008 during three measurement periods $(a-c)$. Precipitation and courses of air temperature are also indicated.

and reached a maximum loss of $11.6 \%$ of the fertilized N. Similar to measurements in 2007 , the emissions started immediately following fertilization and peaked on the second day (Figs 3(a)-(c)). In the absence of rainfall, $80 \%$ of the $\mathrm{NH}_{3}$ losses also occurred within 3 days (Fig. 3(a)). The second and third $\mathrm{NH}_{3}$ emission periods were prematurely terminated due to high rainfall events of $32.5 \mathrm{~mm}$ on the fourth day after fertilization and $22.0 \mathrm{~mm}$ on the second day after fertilization, respectively (Figs $3(b)$ and $(c)$ ).

In 2008, highly significant differences were detected between treatments $(P \leqslant 0.001)$ and application dates $(P \leqslant 0 \cdot 001)$, and a significant interaction was observed between treatments and application dates $(P \leqslant 0 \cdot 05)$. In all measurements, the addition of 2-NPT in both concentrations of $1.5 \mathrm{~g} / \mathrm{kg} \mathrm{N}(P \leqslant 0.05$ for the first and $P \leqslant 0.001$ for the second and third measurement period) and $0.75 \mathrm{~g} / \mathrm{kg} \mathrm{N}(P \leqslant 0.05, \leqslant 0.001$ and $\leqslant$ 0.01 for the first, second and third measurement periods, respectively) significantly mitigated $\mathrm{NH}_{3}$ losses from granulated urea (Table 2). These reductions ranged from 70 to $100 \%$ and from 74 to $84 \%$ for UI concentrations of 1.5 and $0.75 \mathrm{~g} / \mathrm{kg} \mathrm{N}$, respectively.

In contrast to measurements conducted in 2007, fertilization significantly increased grass yield $(P \leqslant 0 \cdot 05)$. Again, no differences in yield were detected between fertilizer treatments (data not shown).

\section{DISCUSSION}

Ammonia emissions from urea-treated plots

All experimental periods except the first one were initiated at the beginning of an expected warmer and rainless phase after a period of precipitation. Following the fertilization of granulated urea, an increase in $\mathrm{NH}_{3}$ emissions could be detected immediately after fertilization. The highest emission values were detected on the second day, which is in line with common findings in the literature of emission peaks occurring 1-3 days after fertilization (Black et al. 1987; Watson et al. 1994; Sherlock et al. 1995; Van Der Weerden \& Jarvis 1997; Dawar et al. 2011; SanzCobena et al. 2011). At 3-6 days, the duration of the loss phase also was comparable to periods of 3-7 days described in the literature (Black et al. 1987; Dawar et al. 2011; Sanz-Cobena et al. 2011). A comparison of sums of $\mathrm{NH}_{3}$ emissions measured within 10 or even 7 days showed no differences and thus indicated that measurement periods of 7 days might be sufficient.

\section{Environmental conditions}

The key factors affecting $\mathrm{NH}_{3}$ emissions from urea-fertilized grassland have been reported in the literature as 
being temperature, precipitation and top-soil water content at the time of fertilization (Sommer et al. 2004). Similar to observations by Black et al. (1987), the dry soil surface at the start of the first experiment in 2007 resulted in reduced $\mathrm{NH}_{3}$ losses, which amounted only to $3.3 \%$ of the applied $\mathrm{N}$ until the first precipitation event 6 days after fertilization on 11 June 2007. In the following measurement periods, fertilization was always performed immediately after a period of precipitation to ensure high soil moisture content, and, corresponding to statements by Black et al. (1987) and Van Der Weerden \& Jarvis (1997), a rapid dissolution of the fertilizer granules and consequent hydrolysis of urea. As a result, at temperatures similar to those of the first measurement period in 2007 the $\mathrm{NH}_{3}$ emissions were considerably higher in the following experiments.

The progress of $\mathrm{NH}_{3}$ emissions is known to be directly influenced by temperature (Ernst \& Massey 1960; Sherlock et al. 1995). In both years, this effect can be seen as daily $\mathrm{NH}_{3}$ emission peaks from urea coinciding with the daily temperature peak. However, observations by Van Der Weerden \& Jarvis (1997) are also supported by these experiments, i.e., the influence of the soil surface humidity at time of fertilization was greater than the temperature effect.

Furthermore, precipitation occurring after the application of granulated urea played a decisive role in the progress of $\mathrm{NH}_{3}$ emissions. Generally, the results of Black et al. (1987) could be confirmed, that the nearer the precipitation event occurred after the date of fertilization, the higher was its emission-terminating or reducing effect. This effect could be observed during the second experiment of 2007 and the third experiment of 2008, where precipitation amounts of 3.8 and $22.0 \mathrm{~mm}$, respectively, on the second day dramatically reduced $\mathrm{NH}_{3}$ emissions. In the second measurement in 2008, a precipitation of $32.5 \mathrm{~mm}$ on 27 June terminated high emissions. The enhancement effect of low precipitation on $\mathrm{NH}_{3}$ losses (Van Der Weerden \& Jarvis 1997) was observed during the fourth experiment in 2007, where a precipitation of $0.9 \mathrm{~mm}$ on day 2 induced further peaks in $\mathrm{NH}_{3}$ emissions. Black et al. (1987) and Zhu et al. (2000) observed in pasture and in maize, respectively, that after fertilization onto an initially dry soil, a late precipitation permitted a further dissolution and hydrolysis of additional urea, and allowed the volatilization of $\mathrm{NH}_{3}$ to start. This effect was also observed during the first measurement period in 2007, where an emission peak occurred 6 days after fertilization induced by precipitation of $3.8 \mathrm{~mm}$ on the previous day. Comparatively low $\mathrm{NH}_{3}$ losses of $4 \cdot 2 \%$ of the fertilized $\mathrm{N}$ supported observations made by Zhu et al. (2000) that a delay in $\mathrm{NH}_{3}$ emissions, caused by dry soil conditions at the time of fertilization, led to lower $\mathrm{NH}_{3}$ losses. In the current work, these losses were also clearly lower than those detected immediately after fertilization.

Even though effects of climatic and soil factors on $\mathrm{NH}_{3}$ emissions were observed as described above, no significant relationships between $\mathrm{NH}_{3}$ emissions and air temperature, soil temperature, soil humidity, maximum temperature or precipitation could be detected.

Effect of $\mathrm{N}$-(2-nitrophenyl) phosphoric triamide on ammonia volatilization

The use of urea as a chemical fertilizer to grassland is generally considered not to be efficient because high amounts of the fertilized $\mathrm{N}$ can be lost as $\mathrm{NH}_{3}$. In the current work, urea was applied to grassland under favourable conditions for high $\mathrm{NH}_{3}$ losses to evaluate the potential of the UI 2-NPT. Watson (2000) summarized the major importance of a UI as: 'slowing the hydrolysis of urea and thus allowing more time for the urea to diffuse away from the application site or for rain or irrigation to dilute urea and $\mathrm{NH}_{4}^{+}$concentration at the soil surface and increase its dispersion into the soil.' The UI 2-NPT in a concentration of $1.0 \mathrm{~g} / \mathrm{kg} \mathrm{N}$ successfully reduced urea hydrolysis for 7 days after fertilization, until precipitation of $8.4 \mathrm{~mm}$ terminated the loss phase. When adding 2-NPT to granulated urea at concentrations of $0.75,1.0$ and $1.5 \mathrm{~g} / \mathrm{kg} \mathrm{N}$, no delay in the effectiveness of 2-NPT could be detected. Ammonia emissions were reduced right from the start. This can be explained by the fact that the UI 2-NPT is added to the urea granule in its active form, and thus does not have to be converted to that form first. The UI did not delay the time of the maximum loss, but reliably mitigated $\mathrm{NH}_{3}$ emissions throughout the whole loss period. The progression of $\mathrm{NH}_{3}$ emissions from urea $+2-N P T$ was similarly influenced by precipitation and the daily course of temperature, as described above for urea alone, but it remained at a lower level. The addition of 2-NPT successfully inhibited the hydrolysis of urea and abated $\mathrm{NH}_{3}$ losses by $74-84 \%$ for a UI concentration of $0 \cdot 75 \mathrm{~g} / \mathrm{kg} \mathrm{N}$, by $69-88 \%$ for a concentration of $1.0 \mathrm{~g} / \mathrm{kg} \mathrm{N}$, and by $70-100 \%$ for a concentration 
of $1.5 \mathrm{~g} / \mathrm{kg} \mathrm{N}$, indicating that already $0.75 \mathrm{~g} / \mathrm{kg} \mathrm{N}$ would be an optimum level.

The addition of 2-NPT at a concentration of $1.0 \mathrm{~g} / \mathrm{kg}$ $\mathrm{N}$ achieved a reduction in $\mathrm{NH}_{3}$ emissions to a level not significantly different from that following the application of CAN. In absolute numbers, however, $\mathrm{NH}_{3}$ volatilization following the application of CAN was still clearly lower and congruent with observations made by Watson et al. (1990) and by Van Der Weerden \& Jarvis (1997), who detected losses at the same magnitude of $0 \cdot 1-0 \cdot 8 \%$ of the fertilized $\mathrm{N}$ applied as CAN.

\section{Impact of the measurement technique}

Following the application of urea to grassland, total $\mathrm{NH}_{3}$ losses of 6 up to $30 \%$ of the fertilized $\mathrm{N}$ have been reported in the literature (Watson et al. 1994; Van Der Weerden \& Jarvis 1997; Dawar et al. 2011; Sanz-Cobena et al. 2011). Although climatic and soil conditions at the time of fertilization were chosen to ensure high $\mathrm{NH}_{3}$ losses in the current experiments, $\mathrm{cu}-$ mulative $\mathrm{NH}_{3}$ emissions were comparatively low, averaging $9 \cdot 1 \%$ in 2007 and $7 \cdot 2 \%$ in 2008 with maximum losses of 14 and $11 \cdot 6 \%$ of the applied N, respectively. Closed measurement systems may generally underestimate losses (Pihlatie et al. 2013) because the air exchange rates used in the ventilated enclosures (in the current case 0.8 volume changes/min) may not fully mimic real field conditions. The measurement system used in the current work was mainly used for comparative studies between different forms of fertilizer or fertilization strategies. Results should be interpreted with care regarding absolute values; however, as was also stated by Misselbrook et al. (2005), the results are reliable regarding the comparison of relative differences in $\mathrm{NH}_{3}$ emissions between different fertilizers or fertilization strategies.

\section{CONCLUSIONS}

Ammonia losses following the application of granulated urea are known to be higher on grassland than on arable land. However, the extent of volatilization is highly dependent on diverse climatic parameters. When urea is chosen as a chemical fertilizer based on agronomic consideration and the incorporation of the fertilizer is not feasible, the addition of a UI is an alternative for reducing $\mathrm{NH}_{3}$ emissions.

The addition of 2-NPT successfully inhibited the hydrolysis of urea and abated $\mathrm{NH}_{3}$ losses by $74-84 \%$ for a UI concentration of $0.75 \mathrm{~g} / \mathrm{kg} \mathrm{N}$, by $69-88 \%$ for a concentration of $1.0 \mathrm{~g} / \mathrm{kg} \mathrm{N}$, and by $70-100 \%$ for a concentration of $1.5 \mathrm{~g} / \mathrm{kg} \mathrm{N}$.

We thank SKW Stickstoffwerke Piesteritz GmbH for financially supporting this project, Josef Glas, Rudolf Heigl, Reinhold Manhart and Christine Haas for their assistance in field and laboratory work, as well as Markus Dolic for his assistance in proofreading.

\section{REFERENCES}

Black, A. S., SHerlock, R. R. \& SMith, N. P. (1987). Effect of timing of simulated rainfall on ammonia volatilization from urea, applied to soil of varying moisture content. Journal of Soil Science 38, 679-687.

Boumman, A.F. \& Van Vuuren, D.P. (1999). Global Assessment of Acidification and Eutrophication of Natural Ecosystems. RIVM report 402001012. Bithoven, The Netherlands: National Institute of Public Health and the Environment.

Dawar, K., Zaman, M., Rowarth, J.S., Blennerhassett, J. \& TuRnBulL, M. H. (2011). Urease inhibitor reduces $N$ losses and improves plant-bioavailability of urea applied in fine particle and granular forms under field conditions. Agriculture, Ecosystems \& Environment 144, 41-50.

ERnST, J.W. \& MASSEY, H. F. (1960). The effects of several factors on volatilization of ammonia formed from urea in the soil. Soil Science Society of America Journal 24, $87-90$

Gee, G. W. \& Bauder, J. W. (1986). Particle size analysis. In Methods of Soil Analysis - Part 1: Physical and Mineralogical Methods, 2nd edn (Ed. A. Klute), pp. 383411. Madison, WI: American Society of Agronomy \& Soil Science Society of America.

Hucke, A., Niclas, H.-J., Wozniak, H., Michel, H.-J. \& SCHUSTER, C. (2010). N-phenylphosphoric Acid Triamides, Method for the Production thereof and their use as Agents for Regulating or Inhibiting Enzymatic Urea Hydrolysis. US Patent. Alexandria, VA: United States Patent and Trademark Office, PCT No.: PCT/ EP2005/001157. Available from: http://www.google.co. uk/patents/US7855189 (accessed 15 October 2015).

IFADATA (2015). World Nitrogen Fertilizer Consumption 2013. Paris, France: IFA. Available from: http://ifadata. fertilizer.org/ucSearch.aspx (accessed 12 July 2015).

IUSS Working Group WRB (2007). World Reference Base for Soil Resources 2006. First Update 2007. World Soil Resources Reports No. 103. Rome: FAO.

Kandeler, E. \& Gerber, H. (1988). Short-term assay of soil urease activity using colorimetric determination of ammonium. Biology and Fertility of Soils 6, 68-72.

Khalil, M. I., Buegger, F., Schraml, M., Gutser, R., SChmidhalter, U. \& Richards, K. G. (2009). Gaseous nitrogen losses from a Cambisol cropped to spring wheat with urea sizes and placement depths. Soil Science Society of America Journal 73, 1335-1344. 
Loeppert, R.H. \& Suarez, D. L. (1996). Carbonate and gypsum. In Methods of Soil Analysis - Part 3: Chemical Methods (Eds D. L. Sparks, A. L. Page, P. A. Helmke, R. H. Loeppert, P. N. Soltanpour, M. A. Tabatabai, C. T. Johnston \& M. E. Sumner), pp. 437-474. Madison, WI: Soil Science Society of America, Inc. and American Society of Agronomy.

MEDINA, R. \& RADEL, R. J. (1988). Mechanisms of urease inhibition. In Ammonia Volatilization from Urea Fertilizers (Eds B. R. Bock \& D. E. Kissel), pp. 137-174. Bulletin Y-206. Muscle Shoals, AL: National Fertilizer Development Center.

Misselbrook, T.H., Nicholson, F. A., Chambers, B. J. \& Johnson, R.A. (2005). Measuring ammonia emissions from land applied manure: an intercomparison of commonly used samplers and techniques. Environmental Pollution 135, 389-397.

Nı, K., PACHOlski, A. \& Kage, H. (2014). Ammonia volatilization after application of urea to winter wheat over 3 years affected by novel urease and nitrification inhibitors. Agriculture, Ecosystems \& Environment 197, 184-194.

Pihlatie, M. K., Christiansen, J. R., Aaltonen, H., Korhonen, J. F. J., Nordbo, A., Rasilo, T., Benanti, G., Giebels, M., Helmy, M., Sheehy, J., Jones, S., Juszczak, R., Kiefoth, R., Lobo-Do-Vale, R., Rosa, A. P., Schreiber, P., Serca, D., Vicca, S., Wolf, B. \& Pumpanen, J. (2013). Comparison of static chambers to measure $\mathrm{CH}_{4}$ emissions from soils. Agricultural and Forest Meteorology 171-172, 124-136.

R Development Core Team (2011). R: a Language and Environment for Statistical Computing. Vienna, Austria: R Foundation for Statistical Computing.

Saggar, S., Singh, J., Giltrap, D. L., Zaman, M., Luo, J., Rollo, M., Kim, D. G., Rys, G. \& Van Der Weerden, T. J. (2013). Quantification of reductions in ammonia emissions from fertiliser urea and animal urine in grazed pastures with urease inhibitors for agriculture inventory: New Zealand as a case study. Science of the Total Environment 465, 136-146.

Sanz-Cobena, A., Misselbrook, T., Camp, V. \& Vallejo, A. (2011). Effect of water addition and the urease inhibitor NBPT on the abatement of ammonia emission from surface applied urea. Atmospheric Environment 45, 1517-1524.
SChOfield, R. K. \& TAYLOR, A. W. (1955). The measurement of soil pH. Soil Science Society of America Journal 19, 164-167.

Sherlock, R. R., Freney, J.R., Bacon, P.E. \& Van Der WeERDEN, T.J. (1995). Estimating ammonia volatilization from unsaturated urea fertilized and urine affected soils by an indirect method. Fertilizer Research 40, 197-205.

Sommer, S. G., Schjoerring, J. K. \& Denmead, O. T. (2004). Ammonia emission from mineral fertilizers and fertilized crops. Advances in Agronomy 82, 557-622.

Van Breemen, N., Burrough, P. A., Velthorst, E. J., Van Dobben, H. F., De Wit, T., Ridder, T. B. \& ReIJNDERS, H. F. R. (1982). Soil acidification from atmospheric ammonium sulphate in forest canopy throughfall. Nature 299, 548-550.

Van Der Weerden, T. J. \& Jarvis, S. C. (1997). Ammonia emission factors for $\mathrm{N}$ fertilizers applied to two contrasting grassland soils. Environmental Pollution 95, 205-211.

Watson, C. J. (2000). Urease Activity and Inhibition Principles and Practice. Proceedings No. 454. Colchester, UK: The International Fertiliser Society.

Watson, C. J., Stevens, R.J. \& Laughin, R. J. (1990). Effectiveness of the urease inhibitor NBPT (N-(n-butyl) thiophosphoric triamide) for improving the efficiency of urea for ryegrass production. Fertilizer Research 24, 11-15.

Watson, C. J., Poland, P., Miller, H., Allen, M. D. B., Garrett, M. K. \& Christianson, C. B. (1994). Agronomic assessment and $15 \mathrm{~N}$ recovery of urea amended with the urease inhibitor nBTPT (N-(n-butyl) thiophosphoric triamide) for temperate grassland. Plant and Soil 161, 167-177.

Wendland, M., Diepolder, M. \& Capriel, P. (2012). Leitfaden für die Düngung von Acker- und Grünland, 10th edn. LfLInformation. Freising, Germany: Bayerische Landesanstalt für Landwirtschaft, Freising-Weihenstephan.

Zaman, M. \& BlenNerhassett, J. D. (2010). Effects of the different rates of urease and nitrification inhibitors on gaseous emissions of ammonia and nitrous oxide, nitrate leaching and pasture production from urine patches in an intensive grazed pasture system. Agriculture, Ecosystems \& Environment 136, 236-246.

Zhu, T., Pattey, E. \& Desjardins, R. L. (2000). Relaxed eddy-accumulation technique for measuring ammonia volatilization. Environmental Science \& Technology 34, 199-203. 